\section{Laboratory Method to Estimate Rain-induced Splitting in Cultivated Blueberries}

\author{
Donna A. Marshall ${ }^{1}$, James M. Spiers, and Stephen J. Stringer \\ U.S. Department of Agriculture, Agricultural Research Service, Thad \\ Cochran Southern Horticultural Laboratory, 810 Highway 26 West, P.O. \\ Box 287, Poplarville, MS 39470

\section{Kenneth J. Curry \\ Department of Biological Sciences, University of Southern Mississippi, Hattiesburg, MS 39406}

Additional index words. fruit splitting, fruit cracking, rabbiteye blueberry, Vaccinium ashei, southern highbush blueberry

\begin{abstract}
Preharvest rainfall that occurs when fruit are fully ripe or approaching full ripeness can result in detrimental fruit splitting in rabbiteye and southern highbush blueberries. This study was initiated to develop a laboratory method to model rainrelated incidence of splitting in cultivated blueberries with the goal of predicting the incidence of splitting in blueberry cultivars and selections. Multiyear field surveys of rabbiteye and southern highbush cultivars show that the incidence of rain-related splitting is strongly cultivar-dependent. Laboratory values for forced splitting and naturally occurring rain-related field splitting data show a strong correlation indicating that the incidence of fruit splitting can be accurately estimated by this laboratory method. Soaking the berries in distilled water $14 \mathrm{~h}$ at room temperature gives a confident determination of splitting tendencies. Blueberry breeders and geneticists can use this method to evaluate new potential blueberry cultivars for splitting tendencies as part of routine screening. This would lead to a long-term goal of reducing splitting susceptible blueberry cultivars in commercial plantings.
\end{abstract}

Fruit splitting and cracking occurs in rabbiteye and southern highbush blueberries if they receive preharvest rainfall when fully ripe or approaching full ripeness. The splitting can be particularly severe if the rain follows a long period of dry weather (Austin, 1994; Lyrene and Crocker, 1991; Rooks et al., 1995). Splits in blueberries are usually oblong wounds in the fruit skin that may be a small, shallow crack in the skin alone or, more commonly, deep wounds that penetrate into the fruit pulp. Deep wounds suggest the initiation of cracking is deep within the fruit and not solely confined to the surface. Whatever the severity, all splitting renders the fruit unmarketable. Growers in Mississippi and Louisiana have reported as much as $20 \%$ crop loss on highly susceptible blueberry cultivars (Marshall et al., 2006).

For many years, researchers have studied rain-induced splitting in sweet cherries, tomatoes, and grapes. Susceptibility to splitting in cherries appears to be related to the rate and quantity of water uptake by the fruit (Belman and Keulemans, 1996). Uptake of water into the fruit occurs not only through the vascular tissue of the pedicel, but also through the skin. It was originally thought

Received for publication 8 June 2007. Accepted for publication 24 Aug. 2007.

${ }^{1}$ To whom reprint requests should be addressed; e-mail DAMarshall@msa-stoneville.ars.usda.gov that water was entering the fruit through stomata (Schönherr and Bukovac, 1972), but results were inconsistent. Several hypotheses have been suggested to explain cracking in cherries, but none with a definitive causal relationship. It is generally agreed (Ackley and Krueger, 1980; Anderson and Richardson, 1982; Bullock, 1952; Davenport et al., 1972; Zielinski, 1964) that the direct or indirect cause of cracking in cherries is the absorption of external water through the fruit skin.

Fruit cracking in tomatoes is reported to be the result of environmental factors that cause cell expansion in the outer ovary wall tissue (Lancaster, 1984). Many factors affect incidence and severity of fruit cracking, but rainfall and soil moisture variations appear to have the greatest influence (Kamimura, 1977). Frazier (1934) reported that cracking indices were higher for plants irrigated after a dry period than for plants kept at constant soil moisture. Pallais (1984) speculated that rapid water uptake and its translocation to the fruit resulted in stress from water overload causing the fruit to crack. He stated that fruit cracking incidence in tomatoes increased with increasing soil moisture or decreasing evapotranspiration. Reynard (1951), Hepler (1961), and Kamimura (1977) agreed that no cultural practices would eliminate, or even consistently reduce, tomato fruit cracking; therefore, methods for testing genetic resistance need to be found.
Cracking or splitting in grapes occurs at points of greatest weakness in the skin. Environmental factors are not the sole reason for fruit cracking in grapes, but they do contribute to susceptibility. Cool and humid days with little wind toward the end of the growing season after irrigation or rainfall present ideal circumstances for splitting (Considine and Kriedemann, 1972). Under these conditions, berries reach maximum turgor. Meynhardt (1964) found a high positive correlation $(\mathrm{r}=0.72 ; P=0.05)$ between overnight relative humidity above $95 \%$ and fruit splitting. Physiological factors have been examined for their role in fruit cracking. Immersing whole fruit in water or misting fruit on a bench was found to be an effective method of causing artificial fruit splitting in grapes (Duke, 1987).

Cultivated blueberries also suffer from rain-related splitting, yet little research has been done on splitting in this crop. In a previous study, Marshall (2001) found that water absorbed through the epidermis of the skin as well as from the roots contributes to splitting. Covering plants, like in a tunnel horticulture that protects plants from rain reaching and standing on the fruit, was not sufficient to eliminate splitting. Furthermore, some berry splitting did occur in covered plants suggesting that water uptake from the roots supplied enough water to cause minimal splitting. Marshall et al. (2002) also found no significant correlation relating levels of soluble solids (SS), total solids (TS), titratable acidity (TA), or the ration of SS/TA in 'Tifblue' and 'Premier' fruit to the frequency of splitting.

Finding a method to determine splitting susceptibility would be a great asset to blueberry breeders and ultimately to the blueberry growers. This study was initiated to develop a laboratory method to identify the rain-related incidence of splitting in cultivated blueberries. We suggest that this method will allow blueberry breeders to evaluate new potential blueberry cultivars for splitting tendencies that meet a long-term goal of reducing splitting susceptible blueberries in commercial plantings.

\section{Materials and Methods}

Study 1. Rain-induced splitting. Field surveys were taken in 1995, 1997, and 1999 on five blueberry cultivars. Blueberries surveyed for field incidence of rain-related splitting were grown in the U.S. Department of Agriculture, Agricultural Research Service (USDA-ARS), Small Fruits Research Station's research plantings in Poplarville and Wiggins, MS. Rabbiteye fruit were harvested from cultivar evaluation plots that were planted in 1985 in a completely random design with four one-plant replications of each cultivar. Fruit from the southern highbush cultivars 'Magnolia' and 'Jubilee' were taken from individual four-plant plots of each cultivar. Each plant was considered a replication. Plants were grown according to commercial practices recommended for this area 
(Spiers et al., 1985). Berries were sampled 15 May to 20 June with the exact dates determined by what cultivar was commercially ripe when it rained. Within $2 \mathrm{~d}$ after rainfall, $1.4 \mathrm{~L}$ of ripe fruit were harvested from each treatment unit of the following cultivars: 'Magnolia', 'Jubilee', 'Premier', 'Tifblue', and 'Climax'. A subsample of 100 fruit from each cultivar was examined for splitting. A berry with a visible tear in the cuticle $1 \mathrm{~mm}$ or longer was considered split. Splits were counted and percent splits were calculated. Data were analyzed by analysis of variance using SAS (SAS Institute, 2001).

Study 2. Developing laboratory methodology, 2000. In 2000, experiments were conducted at the USDA-ARS, Small Fruits Research Service's research plantings in Poplarville, MS, using two rabbiteye blueberry (Vaccinium ashei Reade) cultivars, 'Tifblue', which is prone to fruit splitting, and 'Premier', which is less likely to split (Austin, 1994). Plants were established in 1985 in a Ruston fine sandy loam soil, spaced, and managed (except for irrigation) according to commercial recommendations for Mississippi (Spiers et al., 1985). Because these cultivars have different ripening periods ('Tifblue', midseason to late; and 'Premier', early), identical studies (with the exception of number of sampling dates) were conducted separately for each cultivar. Each experiment was set up as a split plot design. There were four replications of two plants per experimental plot and two border plants between each treatment. Main treatments consisted of two soil moisture conditions, wet and dry. Dry soil conditions were maintained by sheltering plants from rain using $3 \mathrm{~m} \times 6 \mathrm{~m}$ metal-framed, portable canopies covered by clear polyethylene. This covering was used only during rainfall (21 and 22 May, $7.0 \mathrm{~cm} ; 14$ to 20 June, $2.7 \mathrm{~cm}$ ) and removed at other times to minimize variability in microclimate between treatments. Dry-soil plants were irrigated at a rate of $8 \mathrm{~L} /$ week, whereas wet soil plants received $24 \mathrm{~L} /$ week. Soil samples were taken to monitor soil moisture conditions. 'Premier' ripened 15 May to 2 June 2000 when daily high temperatures ranged between 85 and $96^{\circ} \mathrm{F}$ with an average of $92.0^{\circ} \mathrm{F}$. 'Tifblue' ripened 5 to 22 June 2000 when daily high temperatures ranged between 81 and $96{ }^{\circ} \mathrm{F}$ with an average of $91.6^{\circ} \mathrm{F}$.

Incidence of splitting of each cultivar was determined after berries were subjected to soaking in water. Fifteen sound berries (free of visible tears or splits) with pedicel attached and 15 without a pedicel were placed into 250-mL glass Pyrex (Corning, Corning, NY) beakers and covered with distilled (to approximate rainwater, $0.002 \mathrm{mS}$ ) or tap (to approximate overhead irrigation, $0.2 \mathrm{mS}$ ) water. An additional $100-\mathrm{mL}$ glass Pyrex beaker was placed diagonally on top of the fruit to ensure that the entire fruit was submerged. In tomatoes (Phelps, 1985) and cherries (Harding, 1983), fruit were recommended to be submerged for 3 and $4 \mathrm{~h}$, respectively, for cracking to occur. Yet after
$6 \mathrm{~h}$, even the most susceptible cultivars of blueberries had not yet begun to split. Berries were therefore submersed for $14 \mathrm{~h}$ (overnight). Number of split fruit was counted and percent splitting was calculated. Data were analyzed by analysis of variance using SAS (SAS Institute, 2001).

Study 3. Using the laboratory (MS) method to evaluated highbush and rabbiteye blueberries for fruit splitting. Experiments were conducted at the USDA-ARS, Small Fruits Research Service's research plantings in 2001 using the same plants as in the Study 1 field survey. Fruit were harvested from 15 May to 20 June with the exact dates determined by time of commercial ripeness. Ripe fruit $(1.4 \mathrm{~L})$ from each cultivar was harvested. Four replications of 40 intact fruit were placed into beakers and filled with distilled water (to approximate rainwater). A smaller beaker was placed on top of the fruit to ensure that floating fruit were completely submerged. Beakers were left on the countertop in the laboratory at room temperature $\left(25^{\circ} \mathrm{C}\right)$ for $14 \mathrm{~h}$. The number of split fruit was counted and percent splitting was calculated. Linear regression PROC GLM (SAS Institute, 2001) was used to evaluate the correlation between the laboratory method (Study 3) and splitting rates in the field (Study 2).

Study 4. Comprehensive study to compare rain versus $M S$ laboratory fruit splitting tendencies. This study was initiated in 2003 to test the laboratory splitting method on a broader scale by including a wider range of cultivars. Rain and laboratory-induced splitting data were compared in 17 rabbiteye cultivars ('Bluebelle', 'Bluechip', 'Avonblue', 'Woodard', 'Flordablue', 'Powderblue', 'Bonita', 'Chaucer', 'Briteblue', 'Homebell', 'Choice', 'Brightwell', 'Delite', 'Baldwin', 'Bluegem', 'Gardenblue', and 'Centurion') and one unnamed rabbiteye. Plants surveyed were grown in the USDAARS, Small Fruits Research Station's research plantings in Wiggins, MS. Fruit were harvested from cultivar evaluation plots that were planted in 1985 in a randomized complete block design. In both the rain and laboratory-induced studies, fruit $(1.4 \mathrm{~L})$ was collected from single plant plots and four replications were collected. Thirty sound fruit were randomly selected from each 1.4L sample. These fruit were subjected to the previously described laboratory method and percentage of fruit splitting was determined. Fruit for laboratory-induced splitting were collected on two occasions (13 May and 20 May). Each picking occurred before a rainfall and no sooner than $7 \mathrm{~d}$ after the rainfall.

Rain-induced splitting was determined from fruit harvested within $2 \mathrm{~d}$ after significant rainfalls (greater than $2.54 \mathrm{~cm}$ ). Fruit were harvested twice during the season on 23 May (after $3.51 \mathrm{~cm}$ on 22 May) and on 9 June (after $7.52 \mathrm{~cm}$ on 7 June). Ripe Fruit (1.4 L) was harvested for natural rain-induced splitting, a subsample of 100 fruit was examined for splits, and splits were counted and percent splits calculated. Linear regression PROC
GLM (SAS Institute, 2001) was used to evaluate the correlation between the laboratory method and splitting rates in the field.

\section{Results and Discussion}

Study 1. Multiyear field surveys of rabbiteye and southern highbush cultivars show that the incidence of rain-related splitting is strongly cultivar-dependent (Table 1). Yearto-year variations within cultivars reflected yearly differences in ripening times and amounts and timing of rainfall. Based on the 3 -year means of rabbiteyes, 'Premier' had the lowest field incidence of splitting, whereas 'Climax' and 'Tifblue' had significantly higher levels of splitting. The southern highbush cultivars 'Magnolia' and 'Jubilee' had a significantly lower incidence of splitting than both 'Climax' and 'Tifblue', but did not differ in splitting tendencies from 'Premier'.

Study 2. 'Tifblue' berries had a higher percentage of splitting than 'Premier' when subjected to the laboratory method. This relationship occurred in the field but has never been simulated in the laboratory. Some splitting occurs in both cultivars naturally and from forced laboratory means regardless of whether fruit developed in dry or moist soil conditions (Table 2$)$. The dry soil plants $(8 \mathrm{~L} /$ week) were not in drought conditions but received one-third of the irrigation water as the wet soil plants (24 L/week). Under these conditions, 'Premier' exhibited more split fruit in wet soil than was found in dry soil conditions, whereas no difference was found in the extent of splitting in 'Tifblue' as affected by soil conditions. Lyrene and Crocker (1991), Austin (1994), and Rooks

Table 1. Rain-related and laboratory splitting incidence of blueberry cultivars by percent.

\begin{tabular}{lccccc}
\hline & \multicolumn{3}{c}{ Field } & \multicolumn{3}{c}{$3 \mathrm{yr}$} & Laboratory \\
\cline { 2 - 5 } Cultivar & 1995 & 1997 & 1999 & Mean & 2001 \\
\hline Climax & 8.3 & 7.5 & 7.3 & $7.7 \mathrm{a}$ & $40.0 \mathrm{a}$ \\
Tifblue & 7.3 & 4.0 & 7.0 & $6.1 \mathrm{a}$ & $28.1 \mathrm{~b}$ \\
Premier & 2.5 & 2.2 & 1.8 & $2.2 \mathrm{~b}$ & $10.6 \mathrm{c}$ \\
Magnolia & 1.0 & 1.5 & 0.8 & $1.1 \mathrm{~b}$ & $0.0 \mathrm{c}$ \\
Jubilee & 2.3 & 2.0 & 1.3 & $1.9 \mathrm{~b}$ & $5.6 \mathrm{c}$ \\
\hline
\end{tabular}

Means within columns followed by different letters differ significantly at $P<0.05$ by Duncan's multiple range test.

Table 2. Percent splits occurring after soaking rabbiteye blueberry fruit for $14 \mathrm{~h}$ as effected by soil conditions, water type, and pedicel attachment.

\begin{tabular}{lcc}
\hline & Premier & Tifblue \\
\hline Soil condition & $5.1 \mathrm{a}$ & $20.7 \mathrm{a}$ \\
$\quad$ Wet & $2.1 \mathrm{~b}$ & $20.7 \mathrm{a}$ \\
$\quad$ Dry & & \\
Water & $6.7 \mathrm{a}$ & $24.6 \mathrm{a}$ \\
$\quad$ Distilled & $0.5 \mathrm{~b}$ & $16.9 \mathrm{~b}$ \\
$\quad$ Tap & & \\
Pedicel & $3.9 \mathrm{a}$ & $19.0 \mathrm{~b}$ \\
$\quad$ Pedicel attached & $3.3 \mathrm{a}$ & $22.4 \mathrm{a}$ \\
$\quad$ Pedicel removed &
\end{tabular}

Means within columns followed by different letters differ significantly at $P<0.05$ by Duncan's multiple range test. 


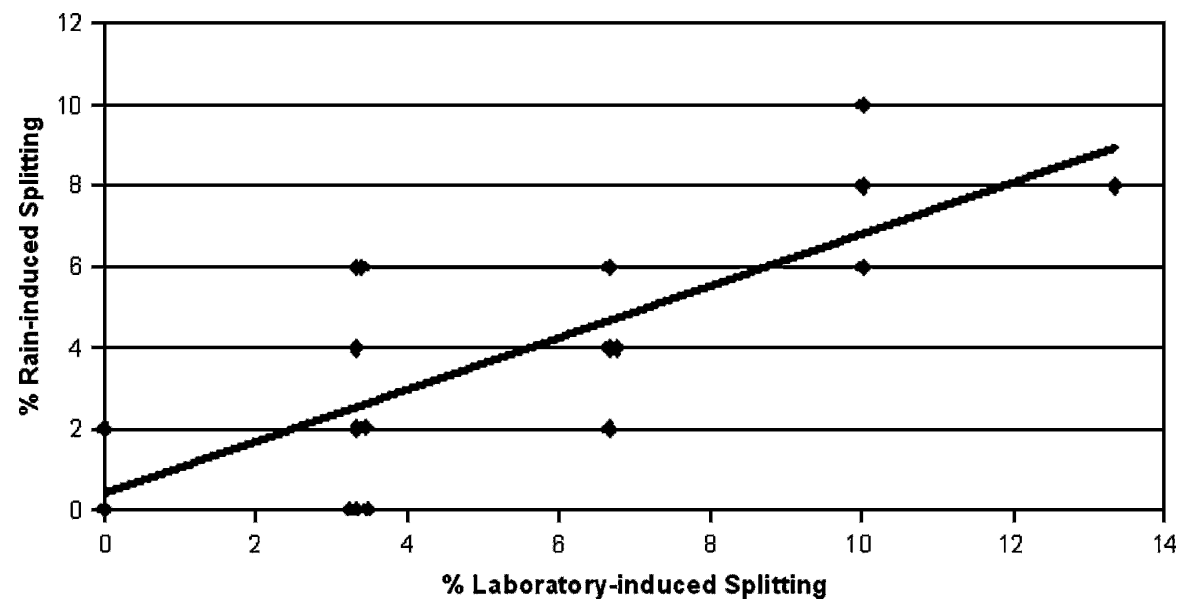

Fig. 1. Linear regression of rain-induced versus laboratory-induced splitting incidence for 18 blueberry cultivars in $2003(n=100)$.

et al. (1995) state that rabbiteye blueberries that develop on drought-stressed plants are more likely to sustain rain-related cracking than are those on plants grown in soil kept moist by irrigation during dry periods. In both cultivars studied, the incidence of splitting is higher if berries are immersed in distilled (rain) water as opposed to tap (overhead irrigation) water. 'Tifblue' fruit has a higher incidence of splitting when the pedicel is removed, exposing the stem scar, a point of weakness. 'Premier' fruit is unaffected by removal of the pedicel.

From this study, we found that 1) blueberry fruit can be forced to split artificially in the laboratory and 2) distilled water is more likely than tap water to split a blueberry fruit under laboratory conditions. Distilled water has lower conductivity than tap water and more closely mimics the effects of rainwater on the fruit.

Study 3. Laboratory-induced splitting showed that 'Climax' had the greatest incidence of splitting followed by 'Tifblue' (Table 1). 'Premier', 'Magnolia', and 'Jubilee' were significantly lower in their incidence of splitting than 'Tifblue' and 'Climax'.

Study 4. The developed laboratory method was tested on 18 blueberry cultivars. There were no differences between individual harvest dates for laboratory-induced or raininduced splitting (data not shown) so data were pooled. A strong relationship $\left(r^{2}=0.75\right)$ between rain-induced splitting of blueberry cultivars and the laboratory method of forced splitting was found (Fig. 1).

\section{Conclusion}

In summary, Study 2 showed that a laboratory method could determine splitting tendencies for two rabbiteye blueberry cultivars, one known to split easily and the other more resistant to splitting. Studies 1 and 3 indicated that five blueberry cultivars varied consistently in both field and laboratoryinduced splitting incidence, and this was highly correlated to laboratory-induced splitting. Study 4 shows that the laboratory method is a good indication of fruit-splitting tendencies over a wide range of blueberry cultivars. Therefore, we believe the incidence of fruit splitting in field conditions can be estimated by the laboratory method consisting of soaking berries in distilled water at room temperature for $14 \mathrm{~h}$ and measuring percent splits. The laboratory method does result in a somewhat higher amount of splitting than rain-induced splitting, but the amount of splitting from the two methods is strongly correlated $\left(r^{2}=0.75\right)$. For screening purposes, geneticists would desire a rigorous and consistent test for splitting susceptibility, and the laboratory method described here and experimentally tested would give a confident determination of blueberry germplasm splitting tendencies.

\section{Literature Cited}

Ackley, W.B. and W.H. Krueger. 1980. Overhead irrigation water quality and the cracking of sweet cherries. HortScience 15:289-290.

Anderson, P.C. and D.G. Richardson. 1982. A rapid method to estimate fruit water status with special reference to rain cracking of sweet cherries. J. Amer. Soc. Hort. Sci. 107:441-444.

Austin, M. 1994. Rabbiteye blueberries, p. 20-21. Agscience, Inc., Auburndale, FL.

Belman, K. and J. Keulemans. 1996. Proc. Intl. Cherry Sym., Acta Hort. 410 ISHS.

Bullock, R.M. 1952. A study of some inorganic compounds and growth promoting chemicals in relation to fruit cracking of 'Bing' cherries at maturity. Proc. Amer. Cos. Hort. Sci. 59:243253.

Considine, J.A. and P.E. Kriedemann. 1972. Fruit splitting in grapes: Determination of the critical turgor pressure. Aust. J. Agr. Res. 23:17-24.

Davenport, D.C., K. Uriu, and R.M. Hagen. 1972. Antitranspirant film: Curtailing intake of exter- nal water by cherry fruit to reduce cracking. HortScience 7:507-508.

Duke, S.D. 1987. Physiological, anatomical, and histological factors associated with fruit cracking of grapes. University of Arkansas, Fayetteville, AK MS Thesis.

Frazier, W.A. 1934. A study of some factors associated with the occurrence of cracking in the tomato fruit. Proc. Amer. Soc. Hort. Sci. 32:519-523.

Harding, P.H. 1983. Testing and cultivar evaluation, p. 371-382. In: J.N. Moore, and J. Janick (eds.). Methods in fruit breeding. Purdue Univ. Press, West Lafayette, IN.

Hepler, R.W. 1961. The measurement and inheritance of resistance to fruit cracking in the tomato. University of Illinois, PhD Diss.

Kamimura, S. 1977. A method of testing crack resistance in tomatoes. Jap. Agr. Res. Q. 5:111114.

Lancaster, D.M. 1984. The inheritance of radial fruit cracking in tomato (Lycopersicon esculentum Mill.). University of Arkansas, Fayetteville, $\mathrm{AK}, \mathrm{PhD}$ Diss.

Lyrene, P.M. and T.E. Crocker. 1991. Commercial blueberry production in Florida. IFAS, Gainesville.

Marshall, D.A. 2001. Physiological differences contributing to the incidence of splitting in 'Premier' and 'Tifblue' rabbiteye blueberries (Vaccinium ashei Reade). University of Southern Mississippi, Thesis.

Marshall, D.A., J.M. Spiers, and J.H. Braswell. 2006. Splitting severity among rabbiteye ( $\mathrm{ac}$ cinium ashei Reade) blueberry cultivars in Mississippi and Louisiana. International Journal of Fruit Science. 6:77-81.

Marshall, D.A., M.J. Spiers, and K.J. Curry. 2002. Incidence of splitting in 'Premier' and 'Tifblue' rabbiteye blueberries, p. 295-303. Proc. 7th International Symposium on Vaccinium. R.F. Hepp (ed.). Acta Hort. 574. ISHS 2002.

Meynhardt, J.T. 1964. Some studies on berry splitting of Queen of the vineyard grape. S. Afr. J. Agr. Sci. 7:179-186.

Pallais, N. 1984. Effects of soil moisutre stress and antitranspirants on the severity of tomato (Lycopersicon esculentum Mill.) fruit cracking, University of Arkansas, Fayetteville. PhD Diss.

Phelps, E.J. 1985. The use of antitranspirants as a selection technique for fruit cracking resistance in tomato. University of Arkansas, Fayetteville, AR, MS Thesis.

Reynard, G.B. 1951. Inherited resistance to radial cracks in tomato fruits. Proc. Amer. Soc. Hort. Sci. 58:231-244.

Rooks, S.D., J.R. Ballington, and C.M. Mainland. 1995. 'Bladen' southern highbush blueberrry. HortScience 30:150-151.

SAS Institute. 2001. SAS/STAT user's guide. Ver. 8.2. SAS Inst., Cary, NC.

Schönherr, J. and M.J. Bukovac. 1972. Penetration of stomata by liquids: Dependence of surface tention, wettability, and stomatal morphology. Plant Phys. 49:813-819.

Spiers, J.M., J.H. Braswell, and C.P. Hegwood, Jr. 1985. Establishment of rabbiteye blueberries. Mississippi Agr. and For. Expt. Stat. Bul 941.

Zielinski, Q.B. 1964. Resistance of sweet cherry varieties to fruit cracking in relation to fruit and pit size and fruit color. Proc. Amer. Soc. Hort. Sci. 84:98-102. 